\begin{tabular}{c} 
Volume and Issues Obtainable at Center for Sustainability Research and Consultancy \\
Journal of Business and Social Review in Emerging Economies \\
ISSN: 2519-089X (E): 2519-0326 \\
Volume 5: No. 1, June 2019 \\
JSRᄃ \\
Journal homepage: www.publishing.globalcsrc.org/jbsee \\
\hline
\end{tabular}

\title{
Use of Social Commerce to Develop Intentions to Buy With Mediating Role of Social Support
}

\author{
${ }^{1}$ Lutf Ullah , ${ }^{2}$ Rehana Kousar, ${ }^{3}$ Irum Saba, ${ }^{4}$ Allah Bakhsh Khan \\ ${ }^{1}$ MPhil Scholar, Department of Commerce, Bahauddin Zakariya University, Multan, Pakistan. \\ lutfi.khaan@gmail.com \\ ${ }^{2}$ Professor, Department of Commerce, Bahauddin Zakariya University, Multan, Pakistan. \\ rehanakousar@bzu.edu.pk \\ ${ }^{3}$ Assistant Professor, IBA Karachi, isaba@iba.edu.pk \\ ${ }^{4}$ Assistant professor, Department of Commerce, Bahauddin Zakariya University, Multan, Pakistan: \\ abkhan@bzu.edu.com
}

\begin{tabular}{|c|c|}
\hline ARTICLE DETAILS & ABSTRACT \\
\hline $\begin{array}{l}\text { History } \\
\text { Revised format: May } 2019 \\
\text { Available Online: June } 2019\end{array}$ & $\begin{array}{l}\text { Web } 2.0 \text { technology and social media have paved a new way for the } \\
\text { communication for individuals and for the businesses of e-commerce } \\
\text { firms. This technology has opened the opportunities to introduce new } \\
\text { business model which incorporates several social aspects of individuals. }\end{array}$ \\
\hline $\begin{array}{l}\text { Keywords } \\
\text { Social Commerce, Social Support, } \\
\text { Trust, Intentions to Buy, } \\
\text { E-Commerce }\end{array}$ & $\begin{array}{l}\text { As Social Networking Sites are gaining more popularity, these have } \\
\text { formed the links between internet consumers and it has become a critical } \\
\text { way of getting knowledge for individuals. It has introduced social } \\
\text { commerce which is joining of three concepts; e-commerce, web } 2.0 \text { and } \\
\text { social media. E-commerce firms have started to engage their potential }\end{array}$ \\
\hline $\begin{array}{l}\text { JEL Classification: } \\
L 80, L 81\end{array}$ & $\begin{array}{l}\text { consumers on social media websites for the sake of contacting potential } \\
\text { consumers and getting feedback on their products and services. Social } \\
\text { Commerce is expanding because of its importance in information sharing. } \\
\text { However, emotional support is also considered important factor which is } \\
\text { comprised of informational and emotional factors that lead to trust and } \\
\text { then ultimately, intentions to buy. This proposed structural model was } \\
\text { assessed through collecting data from the online buyers of Pakistan } \\
\text { through social media. It was found that in order to generate intentions to } \\
\text { buy through social networking sites, social support is vital component that } \\
\text { should be focused by the online businesses. This paper is concluded with } \\
\text { research limitations and some suggestions for future research. }\end{array}$ \\
\hline
\end{tabular}

(C) 2019 The authors, under a Creative Commons Attribution-

NonCommercial 4.0

Corresponding author's email address: rehanakousar@bzu.edu.pk

Recommended citation: Ullah, L., Kousar, R., Saba, I. and Khan, A. B. (2019). Use of Social Commerce to Develop Intentions to Buy With Mediating Role of Social Support. Journal of Business and Social Review in Emerging Economies, 5 (1), 63-78

DOI: $10.26710 /$ jbsee.v5i1.702

\section{Introduction}

Recent innovations and technology enhancements in information technologies and the introduction of web 2.0 have brought new dimensions for development of e-commerce. Social media facilitates this modern platform for business. After continuous development in web 2.0, a new mode for consumer interaction and communication has 
been introduced. Virtual societies and social networking websites are included in this platform. The evolution of social networking has given a modern type of online business which is knows as social commerce (N. Hajli, Shanmugam, Powell, \& Love, 2015).

The development of social technologies i.e. Social Networking Sites (SNSs) is the major cause of development in this field (Liang \& Turban, 2011). These developments provide the platform that attracts the persons to interact with their friends and form an online community. These interactions in online community like on the SNSs, have developed the concept of Social Commerce (Zeng, Huang, \& Dou, 2009). These developments form a contemporary view of the customers (Füller, Mühlbacher, Matzler, \& Jawecki, 2009), on which participate in forums, review other's opinions, rate the products, provide a view of their own knowledge and suggest the products and services to others. According to (Hajli, Lin, Featherman, \& Wang, 2014), the persons co-create the value with the firm. This is the social commerce era in which persons communicate and their communication influence other consumers in order to buy a product (N. Hajli et al., 2014). Social Media mediates the Social Commerce which is related to online communities and SNSs which are growing constantly and speedily (Hajli, 2014a; Hsiao, ChuanChuan Lin, Wang, Lu, \& Yu, 2010; Jeppesen \& Molin, 2003; Shin, 2013).

Social Commerce has opened the opportunities to introduce new business model which incorporates several social aspects of individuals. As SNSs are gaining more popularity, these have forged the links between internet consumers and it has become a critical way of getting knowledge for individuals (Wang \& Chang, 2013). Social Networking Sites are important for both, businesses and individuals as they help to maintain the current social relations and to form new relations among individuals (Constantinides \& Lorenzo-Romero, 2013). In the modern era, growth of online firms has led to a new paradigm which is social commerce. Social Commerce generally refers to applying online social commerce which considers web 2.0 (Z. Huang \& Benyoucef, 2013). According to Linda (2010), Social commerce phenomenon is introduced when three concepts are joined with each other which are ecommerce, web 2.0 and social media(Linda, 2010). E-commerce firms have started to engage their potential consumers on social media websites for the sake of getting feedback on their products and services (N. Hajli et al., 2014). Social Commerce is a shift in the paradigm of business method and introduces a new area for the researchers of information system (Saundage \& Lee, 2011; Shanmugam, Sun, Amidi, Khani, \& Khani, 2016). The ideology of social commerce is based on the fact that it helps individuals and businesses in the transaction, improves communication quality and increases the sale volume which brings loyalty for the e-commerce firm (M. N. Hajli, 2014b). E-commerce evolution into s-commerce is changing the customer role as well. Social Commerce emergence produces the collective bargaining power of the customers as bargaining power has been shifted from sellers to buyers due to the internet usage (N. Hajli \& Sims, 2015; Z. Huang \& Benyoucef, 2013; J. B. Kim, 2012). Thus, customers are the central point of focus for the businesses. Social Commerce has moved the focus from product to customer (Z. Huang \& Benyoucef, 2013; Wigand, Benjamin, \& Birkland, 2008).

Firms are trying to figure out the potential of this technology for operating the business (Shi \& Chow, 2015). eBay and Amazon are the global firms and are considered as pioneer firms in the e-commerce (M. Hajli, 2013). Now a day, these pioneer global e-commerce firms are trying to change market concentration with social media. Amazon introduced the groups having similar interest in the business which allows customers to communicate and form relationships management system for Amazon (Amblee \& Bui, 2011). According to Liu, Cheung, and Lee (2016), social commerce websites are experiencing growth with high speed. According to S.-B. Kim, Sun, and Kim (2013), IT businesses are planning to invest almost US $\$ 50$ billion per year by 2020 in the social commerce.

In the context of social commerce, customers beside communicating also review opinion of others, participate in forums, rate other products, provide view of the knowledge, and suggest some products and services (N. Hajli, 2015a). So because of this, customers can be influenced by other customers and with addition to this, the trust level is increased as trust and security are crucial factors in online platform (N. Hajli \& Lin, 2016; N. Hajli et al., 2014). Trust is a challenging subject for the e-commerce as it includes individuals (Gefen \& Straub, 2004). These individuals are more likely to transact only if there is existence of trust (N. Hajli, 2015a). Therefore, intentions to buy are generated only when trust is developed in the consumers.

Research in the Social Commerce is still in primary phases in spite of much attention has been given to the concept of social (C. Wang \& Zhang, 2012) as Social Commerce understanding is limited and scattered (C. Wang \& Zhang, 2012). Practitioners and information systems need more understanding and explanation of the social commerce 
because it is evolving area of research with less empirically focused and require accurate and deep understanding of the social media practices with business perspective (Saundage \& Lee, 2011).

Researchers have found empirical evidence that trust is influenced by social commerce constructs (N. Hajli, 2015a). This trust leads to intentions to buy. However, in the context of social commerce, a key construct which leads to intentions to buy has been given less attention which is social support constructs. Intentions to buy are generated when there is a trust and trust is built through social support constructs which are emotional support and informational support. It is important to consider these constructs in order to find the factors behind trust and intentions to buy. Based on the N. Hajli (2015a) work on social commerce constructs, a research model is developed in this study which tries to present a link between intentions to buy and social commerce constructs through social support constructs. Thus, following research questions are addressed in this study.

1) Do social commerce constructs effect social support constructs?

2) Do social support measures effect trust?

3) Does trust influence social commerce intention?

Result of the study suggests that social support constructs which are emotional and informational support, are influenced by social commerce constructs and trust is generated by social support constructs which directly leads to the intentions to buy. Moreover, it is also assessed that social support constructs mediate the relationship between trust and social commerce constructs and trust mediates the relationship between social support constructs and intentions to buy.

Rest of the paper is organized into sections. Literature review is presented in the next section and methodology of this study is discussed in section 3. Section 4 deals with the results and analysis which is followed by discussion in section 5. Section 6 presents the conclusion which is followed by research limitations.

\section{Theoretical Background}

\subsection{Social Commerce Constructs and Social Support Constructs}

Individuals communicate in a collaborative online environment on the social commerce platforms (Curty \& Zhang, 2013). The constructs of social commerce are regarded as the platforms for consumers of same network or same group in which they share their ideas and experiences. Forums and communities, ratings and reviews given by the customers, and recommendations and referrals are the examples of social commerce constructs that are necessary for development of social support in the virtual communities (Hajli, 2014a, 2014b). Moreover, experience gained from the online social platforms pave the way for social support. Crocker and Canevello (2008) proposed that interaction of individuals through social commerce constructs leads to social support. Previous studies found that people participate in the purchasing platforms because of social support (Ridings \& Gefen, 2004). This support comprises of emotional and informational support which are inferred from social psychology domain (M. N. Hajli, 2014a; Ridings \& Gefen, 2004). When web 2.0 technology was introduced, it led the boom of social networking sites like Facebook and Twitter. The social networking sites has developed the social support factor and this factor is the major reason of the development of social commerce. Customers obtain social support through social commerce constructs which help the individuals to make decision regarding transaction execution. Hajli (2014a) proposed that social commerce constructs develop the emotional and informational support in the virtual communities. Concluding the above discussion, hypotheses can be developed which are;

H1a: Social commerce constructs affect the emotional support positively.

H1b: Social commerce constructs affect the informational support positively.

\subsection{Social Support Constructs and Trust}

Social support is the construct from the discipline of psychology and it is described as the communication of the individuals in the network in which they are taken care of each other, supported by each other and answered of the question to help each other (Ali, 2011). This network means online community like chat rooms, discussion boards and social networking sites like Twitter (Daneback \& Plantin, 2008; LaCoursiere, 2001). A large number of studies are present on social support in the online context but most of the studies have focused on health sector (Ballantine \& Stephenson, 2011; Obst \& Stafurik, 2010). Relating to the health sector, people try to solve their medical problems by taking information and advice from the people of same network. So, social support is a key element to develop trust in this context. Moreover, a study by Ridings and Gefen (2004) confirmed that main motives behind 
joining online communities for the people is social support and the exchange of relevant information between them. Social support can be characterized as emotional support and informational support that are regarded as important factors in the virtual environment (Coulson, 2005; K.-Y. Huang, Nambisan, \& Uzuner, 2010; Madjar, 2008). A user feels connected to the friends and trust is built for those friends when strong social support is felt (Crocker \& Canevello, 2008; Weber, Johnson, \& Corrigan, 2004). In social commerce, trust is the key challenge. It is being more important for customers as online communities like Facebook are spreading with more speed in modern era (Hajli, 2013). Studies have argued that trust is the vital component in the virtual communities (Gefen, Karahanna, \& Straub, 2003; Mutz, 2005; Pavlou, 2003) and trust can be enhanced by social support in online communities (Gefen et al., 2003). According to Reychav and Weisberg (2010), online environment which facilitates social support can affect trust (Gefen et al., 2003; Mutz, 2005; Pavlou, 2003). M. N. Hajli (2014b) concluded that trust is raised by social support in the virtual community. It has been confirmed that trust is augmented from social support (Crocker \& Canevello, 2008; Hajli, 2014b).

Virtual communities are comprised of both, emotional and informational. The construct emotional support focuses on articulating individuals concerns and helps in problem solving while informational support provides solutions, interpretations and plans regarding information in online environment. In an online community, these two constructs of support become the major support mechanisms for interaction. When social support is felt strongly by individuals, they feel connected to their friends and thus, trust is built for their friends in the virtual communities (Crocker \& Canevello, 2008; Weber et al., 2004). This discussion can be summed up in the following hypotheses.

H2a: Emotional support affect the trust positively.

$\mathrm{H} 2 \mathrm{~b}$ : Informational support affect the trust positively.

\subsection{Trust and Intentions to Buy}

Trust is the vital component in electronic commerce (Gefen \& Straub, 2004; N. Hajli et al., 2014; Mutz, 2005; Pavlou, 2003). Customers try to decrease the risk by relying on familiarities when rules are not adequately adopted (Gefen \& Straub, 2004). Awareness of a specific social networking site tends to increase when individuals' participation in the forums in increased and they see other persons' ratings and reviews about a product (Shanmugam et al., 2016). This creates trust in the deal or the business. Trust creates the power of reducing hesitancy to execute a transaction with an e-vendor (Pavlou, 2003). This power gives the consumer to have a control over transaction (Pavlou, 2003). In the online context, trust is likely to support customers regarding their shopping activities. Studies suggest that consumers' intentions to buy are influenced positively by the trust (Gefen \& Straub, 2004; Pavlou, 2003). In electronic market, trust has a mediating role (Ba \& Pavlou, 2002). This is because trust is a key element to influence the business (Yang, Lin, Chandlrees, \& Chao, 2009). Therefore, it has same effect for social commerce (Shanmugam et al., 2016). Moreover, studies have also found that intentions to buy are developed with the trust as it has a significant role in developing it (Lu, Zhao, \& Wang, 2010; Shin, 2010). When looking for the new products or services in online market, less perceived risk and having confidence are important factors (Hassanein \& Head, 2007; Shin, 2010). Thus, to examine the role of trust in social commerce context is important to figure out whether it leads to intentions to buy or not? Studies analyzing risk in the ecommerce have found that there is an important link among online buying behavior and trust (Ba \& Pavlou, 2002; Gefen, 2002). Thus, we propose that;

H3: Consumers' trust affects the intention to buy positively.

\subsection{Social Commerce Constructs and Trust}

Different studies have revealed that constructs of social commerce i.e. review or ratings of the customers for a product directly affect the trust of the individuals which result in higher sales of the company through social media platform (Swamynathan, Wilson, Boe, Almeroth, \& Zhao, 2008). Positive comments and high ratings of the products significantly support for the building trust (Ba \& Pavlou, 2002). Consumers feel safe and secure in doing transaction with the e-commerce firm when the firm has social presence through social networking sites (Weisberg, Te'eni, \& Arman, 2011) as this presence influence the trust positively (Gefen \& Straub, 2004). The e-vendor presence is felt through social commerce constructs. Therefore, social word of mouth through these social networking sites about the e-vendors influence the trust (S. Kim \& Park, 2013) which can be hypothesized as;

H4: Social Commerce Constructs affect the consumer's trust positively. 


\subsection{Social Commerce Constructs and Intention To Buy}

Studies have also revealed the influence of comments about the product provided by some users affect the intentions to buy of the potential customers significantly (Chen \& Xie, 2005). Major reason behind this impact is that these comments or ratings or provided by those persons who have already used the product and has experience of using it (Forman, Ghose, \& Wiesenfeld, 2008). Thus, individuals take advantage of the other persons' experience. Senecal and Nantel (2004) proposed that these recommendations on the social networking sites has strong effect on the consumer intentions for the products purchase. Information exchange in the virtual community is the basic motive behind the usage of social media and this affect the behavior of the customer positively (Ridings \& Gefen, 2004). Thus, hypothesis can be inferred here as following;

H5: Social Commerce Constructs affect the consumers' intention to buy positively.

\subsection{Structural Model}

From the above hypotheses, a model for social commerce adoption has been developed to understand the social commerce and social relationships of people on internet which help in developing intentions to buy. Specifically, this study focuses on social commerce constructs to develop trust and intentions to buy by considering social support constructs in social commerce environment. This study considers social commerce constructs which are ratings and reviews, forums and communities, and recommendations and referrals; social support constructs which are emotional and informational support, trust and intentions to buy which are deemed as on-going issues in the ecommerce.

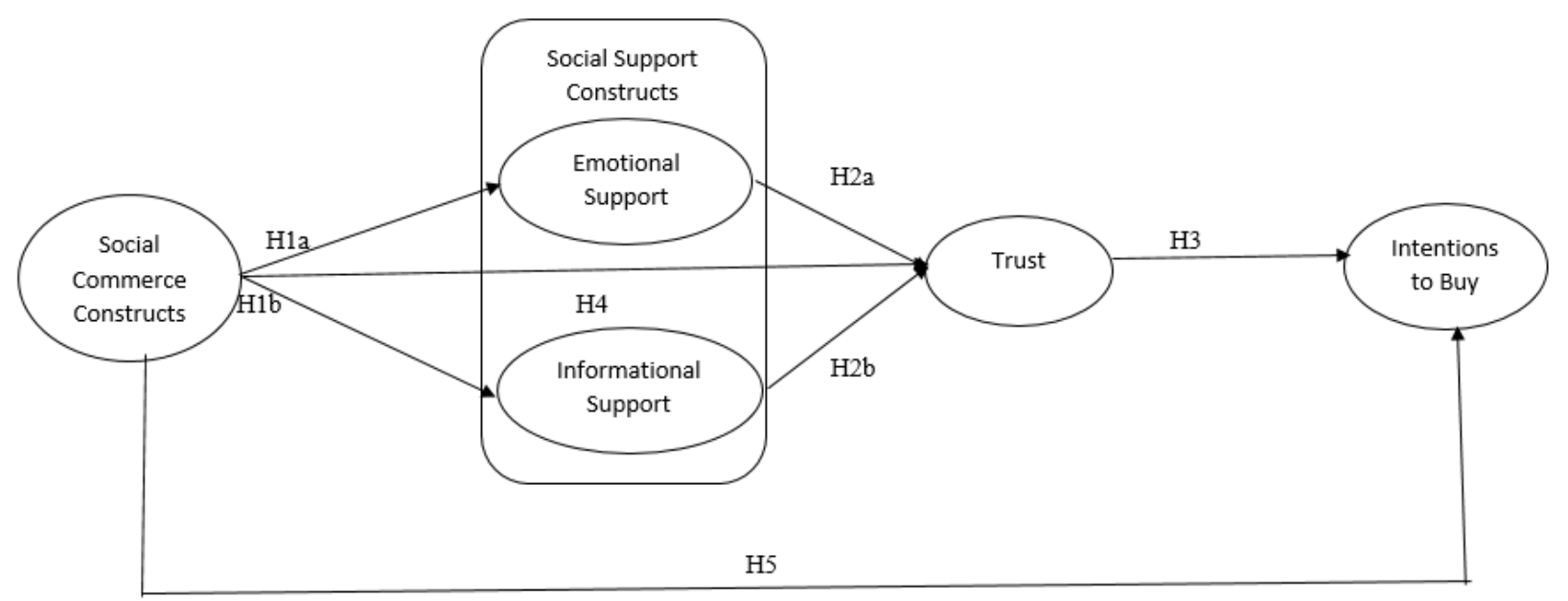

\section{Research Design}

\subsection{Research Instrument}

This study tests the relations and hypotheses empirically. Thus, this study utilizes quantitative approach which is based on the data collected through questionnaires which was developed Therefore, a questionnaire was developed which measured the constructs. Trust measures were taken from S. Kim and Park (2013) who developed these measures by amalgamating and modifying the studies of Vatanasombut, Igbaria, Stylianou, and Rodgers (2008) and Cheung and Lee (2006). Intentions to buy was adapted from N. Hajli (2015b) and S. Kim and Park (2013). Social support includes two dimensions which are emotional and informational support. Emotional support was measured using 4 items which tried to assess the individual's perception that received messages from friends on social networking sites include emotional concerns like empathy, caring and understanding. Informational support was measured using 3 items which tried to assess the individual perception that received messages from friends in social networking sites provide required assistance. Social support was adopted from Shanmugam et al. (2016), who used the items developed by M. N. Hajli (2014a, 2014b); N. Hajli (2015b). Social commerce constructs were measured using 4 items scale which were developed by M. N. Hajli (2014a, 2014b). These measures were altered and modified according to the need of study and were assessed using 5 point Likert scale.

A pilot study was conducted in which questionnaire was submitted to 10 academic and language experts to assess its construction and then it was revised according to their suggestions. Purpose of this pilot study was to make questionnaire easy to understand for the respondents. 


\subsection{Data Collection}

This study is survey based and thus, primary data was collected from the respondents: the persons having at least one-time online transaction through social media. Thus, purposive sampling technique was utilized in the study as it fits best to the need of this study. Data was collected using structured questionnaire which were distributed through emails and Facebook.

\subsubsection{Sample Size}

There are two approaches for selecting sample size which are absolute number size and subject to variable (STV) ratio. Researchers who suggest absolute number size have given different numbers for the sample size like respondents should be 100,150, 200, 250, 300 and 500 while researchers who suggest STV ratio suggest ratio of $2: 1,3: 1,5: 1,6: 1,10: 1.20: 1$ and 30:1. This ratio can be interpreted as for one item, there should be specific number of respondents. We chose subject to variable ratio of 30:1 as it satisfied almost all the arguments which are given by different researchers and satisfied both school of thoughts i.e. Absolute Number Size and STV Ratio, for the appropriate results and factor loading. As this study has 21 items for measurement, target was 630 responses. However, only 476 responses were collected due to non-responding attitude of the online buyers.

\subsubsection{Results}

Data compilation was done for the analyzing the direction and strength of the relations between the constructs. SPSS 24.0 was used for univariate analysis. Multivariate analysis was done through SmartPLS 3.0. SmartPLS is used for second generation multivariate analysis in order to confirm the theoretical aspects of the hypotheses and for confirmation of the model (Ringle, Wende, \& Will, 2005). Thus, this study can be referred to the study following deductive approach (Saunders, 2011).

\subsection{Data Screening and Distribution Analysis \\ 3.3.1 Missing Value Treatment}

The first step is the analysis of data for its accuracy after its collection (Tabachnick, Fidell, \& Osterlind, 2001). As data was collected through online forms, there was no issue of missing responses in the data. Therefore, only data normality property was analyzed only in the SPSS 24.0. PLS-SEM doesn't focus the normality assumption of the data, however, data distribution property analysis is worth considering (Hair Jr, Hult, Ringle, \& Sarstedt, 2016). This property was analyzed through Skewness and Kurtosis assessment in SPSS 24.0 and it was found that distribution of the data is normal as the recommended range of +2.5 and -2.5 was met. Homoscedasticity provides unbiased estimates of the relationship between the independent and dependent variables. In simple words, it points out to the homogeneity of the variance (Joseph F Hair, Anderson, Babin, \& Black, 2010). For the homoscedasticity assessment, Levene test (Levene, 1960) was used through SPSS 24.0 and found that all the p values are lower than 0.05 of the results which satisfied the requirement for homoscedasticity assumption

\subsubsection{Respondents Profile}

Respondents profile was assessed through SPSS 24.0 which represents some diversity in the respondents as it is shown in Table 1.

\section{Table 1: Respondents Demographic Analysis}

\begin{tabular}{|c|c|c|}
\hline Demographic Variable & Frequency & Percentage \\
\hline \multicolumn{3}{|l|}{ Gender } \\
\hline Male & 320 & $67.23 \%$ \\
\hline Female & 156 & $32.77 \%$ \\
\hline \multicolumn{3}{|l|}{ Age } \\
\hline Below 20 & 134 & $28.15 \%$ \\
\hline 21 to 30 & 177 & $37.18 \%$ \\
\hline 31 to 40 & 156 & $32.77 \%$ \\
\hline 41 to 50 & 9 & $1.89 \%$ \\
\hline
\end{tabular}




\begin{tabular}{|c|c|c|}
\hline More than 50 & 0 & $0 \%$ \\
\hline \multicolumn{3}{|l|}{ Education level } \\
\hline High school or below & 40 & $8.40 \%$ \\
\hline College (Intermediate) & 119 & $25 \%$ \\
\hline Graduate school or above & 317 & $66.60 \%$ \\
\hline \multicolumn{3}{|l|}{ Occupation } \\
\hline \multicolumn{3}{|l|}{ Business owner } \\
\hline \multicolumn{3}{|l|}{ Employed } \\
\hline \multicolumn{3}{|l|}{ Unemployed } \\
\hline \multicolumn{3}{|l|}{ Daily Internet Usage } \\
\hline Below 1 hour & 46 & $9.66 \%$ \\
\hline 1 to 3 hours & 189 & $39.71 \%$ \\
\hline 3 to 5 hours & 121 & $25.42 \%$ \\
\hline More than 5 hours & 120 & $25.21 \%$ \\
\hline
\end{tabular}

\subsubsection{Model Assessment}

After analyzing the data accuracy in SPSS 24.0, SmartPLS was used for the evaluation of proposed model. PLS model is divided into two models which are outer model (measurement model) and inner model (structural model). Outer model estimates the relationship between latent variable and the cluster of manifest variables. Inner model measures the relationship between different latent variables.

\section{3..3.4 Outer Model Analysis}

Outer model is assessed through validity and reliability (Hair Jr et al., 2016). Cronbach's alpha is the estimator for international consistency (Cronbach, 1951). As shown in table 4.2, all the variable are found to be having Cronbach's alpha between 0.604 and 0.754 which is more than 0.6 that is the minimum acceptable value of acceptance (Cronbach, 1951; Joe F Hair, Ringle, \& Sarstedt, 2011). The second measure for the reliability is Composite reliability which analyses the robustness with respect to internal consistency. It is also analyzed as Henseler, Ringle, and Sinkovics (2009) concluded "Cronbach's alpha tends to provide a severe underestimation of the internal consistency reliability of latent variables in PLS path models". The result of this study revealed that variables of this study are vigorous as mentioned in Table 4.3. The values were higher than the minimum acceptable value of 0.6 (Nunnally \& Bernstein, 1994; Tenenhaus, Vinzi, Chatelin, \& Lauro, 2005; Werts, Linn, \& Jöreskog, 1974) and were ranging from 0.791 to 0.845.

\section{Table 2: Outer Model Results}

\begin{tabular}{|l|l|l|l|}
\hline Construct & Cronbach's alpha & $\begin{array}{l}\text { Composite } \\
\text { Reliability }\end{array}$ & $\begin{array}{l}\text { Average Variance } \\
\text { Extracted (AVE) }\end{array}$ \\
\hline Emotional Support & 0.670 & 0.819 & 0.602 \\
\hline Informational Support & 0.616 & 0.796 & 0.566 \\
\hline
\end{tabular}




\begin{tabular}{|l|l|l|l|}
\hline Intentions to Buy & 0.754 & 0.845 & 0.577 \\
\hline Social Commerce Constructs & 0.604 & 0.791 & 0.558 \\
\hline Trust & 0.754 & 0.836 & 0.505 \\
\hline
\end{tabular}

The study investigated the reliability of scale items individually through factor loadings of these items for the construct. Outer loadings generation was done through SmartPLS (Ringle et al., 2005). Minimum acceptable criteria of 0.6 (F. Hair Jr et al., 2014; Joe F Hair et al., 2011). was crossed by these items. Some items from emotional support, social commerce constructs and intentions to buy didn't met the acceptable criteria and therefore, they were excluded from the model.

Construct validity is assessed through two criteria in the SmartPLS which are discriminant and convergent validity (F. Hair Jr et al., 2014; Joe F Hair et al., 2011). Convergent validity analyses the theoretically vigorousness of the scale items (F. Hair Jr et al., 2014). It is examined through Average Variance Extracted (AVE) values. The acceptable limit is 0.4 (F. Hair Jr et al., 2014; Henseler et al., 2009) for the AVE values which is surpassed by the constructs in this study as these constructs have values from 0.505 to 0.602 which is mentioned in the Table 3 . It means that operationalization of these constructs has more than $50 \%$ variance in the observed measurement (F. Hair Jr et al., 2014; Götz, Liehr-Gobbers, \& Krafft, 2010).

Another criterion for the measurement of the validity of a construct is the discriminant validity which tests that every variable should be unique from the other constructs (Bagozzi, Yi, \& Phillips, 1991). There are two tests for the discriminant validity which are Fornell-Larcker test and the cross loading analysis (Joe F Hair et al., 2011; Hair Jr et al., 2016). Through SmartPLS, cross loadings matrix was obtained. These loadings are Pearson Correlation Coefficients for their variables which demands that loadings of the variables should be higher than the cross loadings (Götz et al., 2010). This study affirmed this requirement as well, as it is mentioned in the Table 4.

\section{Table 3: Cross Loadings}

\begin{tabular}{|l|l|l|l|l|l|}
\hline & $\begin{array}{l}\text { Emotional } \\
\text { Support }\end{array}$ & Informational Support & Intentions to Buy & $\begin{array}{l}\text { Social Commerce } \\
\text { Constructs }\end{array}$ & Trust \\
\hline ES1 & 0.815 & 0.651 & 0.559 & 0.583 & 0.622 \\
\hline ES2 & 0.734 & 0.510 & 0.482 & 0.432 & 0.537 \\
\hline ES4 & 0.777 & 0.538 & 0.518 & 0.495 & 0.611 \\
\hline IB1 & 0.512 & 0.565 & 0.764 & 0.443 & 0.584 \\
\hline IB2 & 0.534 & 0.546 & 0.721 & 0.436 & 0.555 \\
\hline IB3 & 0.427 & 0.505 & 0.721 & 0.492 & 0.556 \\
\hline IB5 & 0.563 & 0.531 & 0.826 & 0.537 & 0.607 \\
\hline IS1 & 0.575 & 0.794 & 0.547 & 0.567 & 0.604 \\
\hline IS2 & 0.517 & 0.726 & 0.475 & 0.509 & 0.546 \\
\hline IS3 & 0.564 & 0.736 & 0.572 & 0.497 & 0.543 \\
\hline SC1 & 0.483 & 0.535 & 0.455 & 0.736 & 0.527 \\
\hline SC2 & 0.485 & 0.484 & 0.476 & 0.734 & 0.515 \\
\hline SC4 & 0.498 & 0.544 & 0.480 & 0.771 & 0.537 \\
\hline T1 & 0.569 & 0.489 & 0.526 & 0.547 & 0.732 \\
\hline T2 & 0.540 & 0.542 & 0.539 & 0.462 & 0.689 \\
\hline T3 & 0.543 & 0.524 & 0.548 & 0.503 & 0.726 \\
\hline T4 & 0.468 & 0.549 & 0.545 & 0.497 & 0.664 \\
\hline T5 & 0.583 & 0.562 & 0.495 & 0.740 \\
\hline
\end{tabular}

At the construct level, discriminant validity is assessed through Fornell-Larcker criterion (Fornell \& Larcker, 1981). According to this test, the variable should share more variance with its measures as compared to the other variables in the study. Therefore, Square root of Average Variance Extracted (AVE) of a variable should be higher than its correlation with other variables in the model (Fornell \& Larcker, 1981). In this study, requirement of the FornellLarcker test were satisfied which indicated satisfaction for the discriminant validity in the model as shown in the Table 5 . 
Table 4: Latent Variable Correlation

\begin{tabular}{|l|l|l|l|l|l|}
\hline & $\begin{array}{l}\text { Emotional } \\
\text { Support }\end{array}$ & $\begin{array}{l}\text { Informational } \\
\text { Support }\end{array}$ & $\begin{array}{l}\text { Intentions } \\
\text { to Buy }\end{array}$ & $\begin{array}{l}\text { Social } \\
\text { Commerce } \\
\text { Constructs }\end{array}$ & Trust \\
\hline Emotional Support & 0.776 & & & & \\
\hline Informational Support & 0.733 & 0.752 & & & \\
\hline Intentions to Buy & 0.671 & 0.706 & 0.759 & & \\
\hline Social Commerce Constructs & 0.654 & 0.698 & 0.630 & 0.747 & \\
\hline Trust & 0.601 & 0.659 & 0.701 & 0.705 & 0.711 \\
\hline
\end{tabular}

*Diagonal values are the squared root of AVE values

After satisfying the validity and reliability of the model, structural model was assessed based on satisfactory result of outer or measurement model.

\subsubsection{Inner Model}

Inner model or structural model investigates the relation of variables which are identified by the theory (Yaseen, 2015). The estimates determine the level of prediction of these variables as compared to goodness of fit in the Covariance based approach (F. Hair Jr et al., 2014; Hair Jr et al., 2016). Inner or structural model is assessed through four criteria which are coefficient of determination or R2, path coefficients, predictive relevance or Q2, and effect size or $\mathrm{f} 2$ and relative predictive relevance or q2 (Hair Jr et al., 2016).

$\mathrm{R}^{2}$ assess the accuracy of prediction through analyzing joint impact of exogenous constructs on endogenous constructs (F. Hair Jr et al., 2014). R2 is the common criterion for assessing the model predicting accuracy in SmartPLS. Its value ranges from 0 to 1 . Higher value of R2 points out to higher prediction accuracy. R2 values are moderate and strong as their values range from 0.43 and 0.69 . this means that social commerce constructs have explained $43 \%, 49 \%, 59 \%$ and $69 \%$ variance in the emotional support, informational support, intentions to buy and trust respectively.

To analyze the significance through t-values, bootstrapping was done with 5000 resampling with SmartPLS (Hair Jr et al., 2014) as recommended by Preacher and Hayes (2008). Bootstrapping is a technique to estimate the path coefficients precision analysis (Hair $\mathrm{Jr}$ et al., 2014). It measures the standard error and $\mathrm{t}$-values for assessing the path coefficients significance. $\beta$ values are said to be significant if R2 is explaining moderate variance with significant t-values at a specific level of confidence or p-value (F. Hair Jr et al., 2014; Hair Jr et al., 2016). This study finds all the t-values are greater than 2.58 and therefore, $\beta$ is showing two tailed significances at $p<0.01$ as shown in Table 5. This means that all the hypotheses proposed in the study are confirmed.

Along with estimation of predictive accuracy of (R2), it is important to assess the prediction relevance of the model in order to justify the quality of model (F. Hair Jr et al., 2014; Hair Jr et al., 2016). Q2 values demonstrate the collective effect of exogenous variables in predicting the inner models Predictive relevance is measured through Stone-Geisser's Q2 which is the average index of variables (Geisser, 1974; Stone, 1974). Blindfolding process is applied with reflective scales for cross validating values of CV-Redundancy (F2) and CV-Communalities (H2). Range of Q2 values is 0 to 1 and model is expected to have predictive relevance if the value is above zero (Hair Jr et al., 2016). Thus, if the value is high, predictive relevance of the model is also high. Table 6 shows the blindfolding algorithm results through SmartPLS having gap of 6 blocks. Results reveals that all blocks have acceptable value for CV-redundancy and CV-communality as these are above zero (Fornell \& Cha, 1994) which points out that model has predictive relevance.

\section{Table 5: Results for Structural Model}

\begin{tabular}{|l|l|l|l|l|l|}
\hline H & Paths & $(\beta)$ & Standard Error & t-value & Assessment \\
\hline H1a & $\begin{array}{l}\text { Social Commerce Constructs -> Emotional } \\
\text { Support }\end{array}$ & 0.747 & 0.035 & 18.531 & Accepted \\
\hline H1b & $\begin{array}{l}\text { Social Commerce Constructs -> Informational } \\
\text { Support }\end{array}$ & 0.750 & 0.030 & 23.050 & Accepted \\
\hline H2a & Emotional Support -> Trust & 0.434 & 0.044 & 8.740 & Accepted \\
\hline
\end{tabular}




\begin{tabular}{|l|l|l|l|l|l|}
\hline H2b & Informational Support -> Trust & 0.234 & 0.049 & 6.132 & Accepted \\
\hline H3 & Trust -> Intentions to Buy & 0.602 & 0.044 & 14.095 & Accepted \\
\hline H4 & Social Commerce Constructs -> Trust & 0.254 & 0.042 & 5.870 & Accepted \\
\hline H5 & $\begin{array}{l}\text { Social Commerce Constructs -> Intentions to } \\
\text { Buy }\end{array}$ & 0.253 & 0.046 & 4.115 & Accepted \\
\hline
\end{tabular}

Table 6: Predictive Accuracy (R2) and Predictive Relevance (Q2)

\begin{tabular}{|l|l|l|l|}
\hline Variable & R2 & CV-Communality H2 & CV-Redundancy F2 \\
\hline Social Commerce Constructs & - & 0.113 & - \\
\hline Emotional Support & 0.43 & 0.201 & 0.255 \\
\hline Informational Support & 0.49 & 0.131 & 0.273 \\
\hline Intentions to Buy & 0.59 & 0.243 & 0.340 \\
\hline Trust & 0.69 & 0.262 & 0.344 \\
\hline Average & 0.55 & $0.22 *$ & \\
\hline
\end{tabular}

*Weighted Average

The study has found that Social Commerce Constructs have significant direct effect on Intention to buy. However, study also found that the social commerce constructs are positively related to mediating variable which are social support constructs and trust and these mediators are positively related to the dependent variable which is intentions to buy. Therefore, it seems necessary to analyze the mediation effect for the constructs in order to get clear understanding of the mediators' role in the proposed model. This analysis is done through analyzing indirect and direct effect calculated through the SmartPLS and then calculating Variance Accounted For (VAF). Result shows that all the mediations in this model are partial mediations as the values of VAF are lower than 0.8 but higher than 0.2 as 0.8 describes full mediation and 0.2 shows no mediation (F. Hair Jr et al.).

\section{Table 7: Mediation Analysis}

\begin{tabular}{|l|l|l|l|l|l|l|l|}
\hline Hypothesis & Relationship & $\begin{array}{l}\text { Indirect } \\
\text { effect }\end{array}$ & $\begin{array}{l}\text { Total } \\
\text { Effect }\end{array}$ & $\begin{array}{l}\text { Standard } \\
\text { Deviation }\end{array}$ & t-value & VAF* & Results \\
\hline H6 & $\begin{array}{l}\text { Social Commerce Constructs } \\
\text {->Informational support > } \\
\text { Trust }\end{array}$ & 0.353 & 0.705 & 0.037 & 9.717 & 0.50 & $\begin{array}{l}\text { Partial } \\
\text { Mediation }\end{array}$ \\
\hline H7 & $\begin{array}{l}\text { Social Commerce Constructs } \\
\text {-> Emotional support Trust }\end{array}$ & 0.345 & 0.705 & 0.047 & 7.559 & 0.49 & $\begin{array}{l}\text { Partial } \\
\text { Mediation }\end{array}$ \\
\hline H8 & $\begin{array}{l}\text { Social Commerce Constructs } \\
\text {-> Trust> Intentions to Buy }\end{array}$ & 0.441 & 0.630 & 0.042 & 14.854 & 0.7 & $\begin{array}{l}\text { Partial } \\
\text { Mediation }\end{array}$ \\
\hline
\end{tabular}

*VAF=Variance Accounted For $=$ Indirect/total

\section{Discussion}

This study tries to find out the relationship of social commerce constructs and intentions to buy by considering social support constructs in the relation. In other words, antecedents of intentions to buy in the online context were tried to be figured out through quantitative study. A research model was proposed and evaluated in the study which tried to integrate the social commerce constructs, social support constructs which has emotional and informational support constructs, trust for the online businesses and intentions to buy. This empirical study supported the relations proposed in the study and found that high degree of emotional and informational support can be achieved when social commerce constructs and emotional and informational support exist which lead towards the trust (Hajli 2014) building and then, generating intentions to buy in online context (Hajli 2016). Consumers are more informed now about the products because of the social media and internet. Collecting information about the products is always a first step taken by the consumers in order to purchase it. This information collection process has been made easy by the social media. When this purchase is being done in the online context, the presence of trust is necessary. Trust is the key element in the transaction especially in the online transaction as it defines the obligation of the e-vendor. When trust is built, consumers are more likely to purchase and thus, intention to buy are generated (Hajli 2016). Therefore, it is important to examine the factors that can influence trust in online environment and generate the 
intentions to buy. This study examines social commerce and social support constructs as factors which influence the trust and ultimately, intentions to buy are generated. Findings of this study help to understand the process of building trust and creating intentions to buy in social commerce. More specifically, this study reveals that social commerce constructs cause the higher level of informational and emotional support and these social support constructs cause the higher level of trust of the participants of social commerce which leads to the intention to buy. This empirical investigation of social commerce helps to understand the process of building trust and generation of intentions to buy.

This study is different with previous studies in way that it doesn't consider social support as a second order construct but it takes it as a mediator having its antecedent which is a social commerce construct. By taking social support construct as an antecedent of social support, it explores its effect on social support (N. Hajli, 2015b). Role of these constructs is highlighted for building trust and generating the intentions to buy. Extending the previous studies (M. N. Hajli, 2014a), this study although finds the significant positive impact of social commerce constructs on both constructs of social support but it also reveals that it's significance impact on informational support is higher as compared to the emotional support. Findings of this study reveals the mediating role of social support constructs in order to develop intentions to buy which is one of the contribution of this study. Moreover, this study reveals that trust is built with the integration of constructs of social supports; emotional support and informational support which confirms the findings of (Shanmugam et al., 2016). Therefore, this study is the extension of literature of social support in the context of social support and trust building process. From a practical viewpoint, the importance of social support is highlighted that e-vendors should try to incorporate the social support for the generation of intentions to buy. Thus, it recommends the e-vendors that social support environment should be created on the social networking sites or at their forums in order to develop intentions to buy and increase sales.

\section{Implications of the Study}

This study explores the role of social commerce constructs to increase social support in the online communities which increase trust level and intention to buy.

With respect to the theoretically implications, this study suggests a research model in social commerce. This research is a modest contribution to develop better understanding of social commerce through empirical study by incorporating social support constructs as an effect of social commerce constructs to develop trust and intentions to buy in the modern world of social media.

Practically, this research contributes by emphasizing significance of social platforms which are enabled by web 2.0. Its importance for e-commerce firms to figure out a plan for the reviewers and for managing social media efficiently as consumers' decisions for purchasing is worth studying (Chen \& Xie, 2005). Result of this study provide some guidelines to e-commerce firms to use social commerce efficiently for building trust which can influence the intention to buy of consumers on social networking sites. Social platforms like ratings and reviews, forums and communities, referrals and recommendations are vital components in social commerce for building trust. Thus, e-vendors may engage with customers on these platforms to build trust which leads to purchasing behavior.

This study has several limitations according to its conduct. First, data representativeness is limited. This study was conducted in Pakistan which is a developing country. There is a great difference between virtual markets of a developing country and developed country. So, future research can be conducted in advanced economy to increase its generalizability. Second, 5 point Likert Scale was used in this research and 7 point Likert Scale could provide more appropriate results for the model. Third, data collection was done in only one online community which was Facebook. So, its generalizability is limited. So, results can vary for social commerce constructs if other virtual communities are also considered. Fourth, this study focused on social support to build trust and intention to buy. There may be some other variables which can affect this model. Future researchers can try to explore other trust building factors and factors behind intention to buy in social commerce. Fifth, as suggested by Shanmugam et al. (2016), age of the participants can affect the model. Age can be used as a moderator on social support. So, future research can be conducted to take age as a moderator in the study.

\section{Conclusion}

This study tries to offer better knowledge on the social commerce. Trust has got great attention from researchers in social commerce context. This is due to the fact that trust is a bridge between social commerce constructs and 
intention to buy. To investigate how intentions to buy are generated in social commerce context, this study proposed a framework based on theories of social commerce and social support. Social commerce constructs which are referrals, recommendations, ratings, reviews, forums and communities are the important constructs of social commerce. Based on it, a survey approach was used to collect the data from Facebook users who had executed a transaction online. This data was analysed through structured equation modelling to test the hypotheses. Findings of the empirical study using PLS-SEM emphasize the impact of social support in order to generate intentions to buy. Results of this study state that social commerce constructs cause higher informational and emotional support. This support which includes informational and emotional support, increases users' trust on virtual communities. This study also found that trust leads to developing the intentions to buy which is consistent with previous researches on Technology Acceptance Model. Major finding of this study is that social commerce constructs developed from web 2.0, showed that interactions and relationships of users' have positive impact on the customer behavior. It is also revealed that social commerce constructs provide opportunity for sharing information, contribution, collaboration and co-creation between and have positive impact on intention to buy. Results concludes that for e-commerce firms, it is necessary to create such platform that brings the customers together for sharing their experiencing. This will create opportunity for designing an effective strategy which will be beneficial for both, consumers and vendors.

In nutshell, this research examines the social support constructs role for generating consumer's intention to buy through social commerce constructs and hence provide some novel findings.

\section{References}

Ali, H. (2011). Exchanging value within individuals' networks: Social support implications for health marketers. Journal of marketing Management, 27(3-4), 316-335.

Amblee, N., \& Bui, T. (2011). Harnessing the influence of social proof in online shopping: The effect of electronic word of mouth on sales of digital microproducts. International Journal of electronic commerce, 16(2), 91114.

Ba, S., \& Pavlou, P. A. (2002). Evidence of the effect of trust building technology in electronic markets: Price premiums and buyer behavior. MIS quarterly, 243-268.

Bagozzi, R. P., Yi, Y., \& Phillips, L. W. (1991). Assessing construct validity in organizational research. Administrative science quarterly, 421-458.

Ballantine, P. W., \& Stephenson, R. J. (2011). Help me, I'm fat! Social support in online weight loss networks. Journal of Consumer Behaviour, 10(6), 332-337.

Chen, Y., \& Xie, J. (2005). Third-party product review and firm marketing strategy. Marketing Science, 24(2), 218240.

Cheung, C. M., \& Lee, M. K. (2006). Understanding consumer trust in Internet shopping: A multidisciplinary approach. Journal of the American society for Information Science and Technology, 57(4), 479-492.

Constantinides, E., \& Lorenzo-Romero, C. (2013). Social networking sites as business tool: a study of user behavior Business process management (pp. 221-240): Springer.

Coulson, N. S. (2005). Receiving social support online: an analysis of a computer-mediated support group for individuals living with irritable bowel syndrome. Cyberpsychology \& behavior, 8(6), 580-584.

Crocker, J., \& Canevello, A. (2008). Creating and undermining social support in communal relationships: the role of compassionate and self-image goals. Journal of personality and social psychology, 95(3), 555.

Cronbach, L. J. (1951). Coefficient alpha and the internal structure of tests. psychometrika, 16(3), 297-334.

Curty, R. G., \& Zhang, P. (2013). Website features that gave rise to social commerce: a historical analysis. Electronic Commerce Research and Applications, 12(4), 260-279.

Daneback, K., \& Plantin, L. (2008). » Research on Parenthood and the Internet: Themes and Trends «. Cyberpsychology: Journal of Psychosocial Research on Cyberspace, 2 (2), article 1.

F. Hair Jr, J., Sarstedt, M., Hopkins, L., \& G. Kuppelwieser, V. (2014). Partial least squares structural equation modeling (PLS-SEM) An emerging tool in business research. European Business Review, 26(2), 106-121.

Forman, C., Ghose, A., \& Wiesenfeld, B. (2008). Examining the relationship between reviews and sales: The role of reviewer identity disclosure in electronic markets. Information Systems Research, 19(3), 291-313.

Fornell, C., \& Cha, J. (1994). Partial least squares. Advanced methods of marketing research, 407(3), 52-78.

Fornell, C., \& Larcker, D. F. (1981). Structural equation models with unobservable variables and measurement error: Algebra and statistics. Journal of marketing research, 382-388.

Füller, J., Mühlbacher, H., Matzler, K., \& Jawecki, G. (2009). Consumer empowerment through internet-based cocreation. Journal of Management Information Systems, 26(3), 71-102. 
Gefen, D. (2002). Reflections on the dimensions of trust and trustworthiness among online consumers. ACM Sigmis Database, 33(3), 38-53.

Gefen, D., Karahanna, E., \& Straub, D. W. (2003). Trust and TAM in online shopping: an integrated model. MIS quarterly, 27(1), 51-90.

Gefen, D., \& Straub, D. W. (2004). Consumer trust in B2C e-Commerce and the importance of social presence: experiments in e-Products and e-Services. Omega, 32(6), 407-424.

Geisser, S. (1974). A predictive approach to the random effect model. Biometrika, 101-107.

Götz, O., Liehr-Gobbers, K., \& Krafft, M. (2010). Evaluation of structural equation models using the partial least squares (PLS) approach Handbook of partial least squares (pp. 691-711): Springer.

Hair, J. F., Anderson, R. E., Babin, B. J., \& Black, W. C. (2010). Multivariate data analysis: A global perspective (Vol. 7): Pearson Upper Saddle River, NJ.

Hair, J. F., Ringle, C. M., \& Sarstedt, M. (2011). PLS-SEM: Indeed a silver bullet. Journal of Marketing theory and Practice, 19(2), 139-152.

Hair Jr, J. F., Hult, G. T. M., Ringle, C., \& Sarstedt, M. (2016). A primer on partial least squares structural equation modeling (PLS-SEM): Sage Publications.

Hajli, M. (2013). A research framework for social commerce adoption. Information Management \& Computer Security, 21(3), 144-154.

Hajli, M. N. (2014a). The role of social support on relationship quality and social commerce. Technological Forecasting and Social Change, 87, 17-27.

Hajli, M. N. (2014b). A study of the impact of social media on consumers. International Journal of Market Research, 56(3), 387-404.

Hajli, N. (2015a). Handbook of research on integrating social media into strategic marketing: IGI Global.

Hajli, N. (2015b). Social commerce constructs and consumer's intention to buy. International Journal of Information Management, 35(2), 183-191.

Hajli, N., \& Lin, X. (2016). Exploring the security of information sharing on social networking sites: The role of perceived control of information. Journal of Business Ethics, 133(1), 111-123.

Hajli, N., Lin, X., Featherman, M. S., \& Wang, Y. (2014). Social word of mouth: How trust develops in the market.

Hajli, N., Shanmugam, M., Powell, P., \& Love, P. E. (2015). A study on the continuance participation in on-line communities with social commerce perspective. Technological Forecasting and Social Change, 96, 232241.

Hajli, N., \& Sims, J. (2015). Social commerce: The transfer of power from sellers to buyers. Technological Forecasting and Social Change, 94, 350-358.

Hassanein, K., \& Head, M. (2007). Manipulating perceived social presence through the web interface and its impact on attitude towards online shopping. International Journal of Human-Computer Studies, 65(8), 689708.

Henseler, J., Ringle, C. M., \& Sinkovics, R. R. (2009). The use of partial least squares path modeling in international marketing New challenges to international marketing (pp. 277-319): Emerald Group Publishing Limited.

Hsiao, K.-L., Chuan-Chuan Lin, J., Wang, X.-Y., Lu, H.-P., \& Yu, H. (2010). Antecedents and consequences of trust in online product recommendations: An empirical study in social shopping. Online Information Review, 34(6), 935-953.

Huang, K.-Y., Nambisan, P., \& Uzuner, Ö. (2010). Informational Support or Emotional Support: Preliminary Study of an Automated Approach to Analyze Online Support Community Contents. Paper presented at the ICIS.

Huang, Z., \& Benyoucef, M. (2013). User-centered investigation of social commerce design. Paper presented at the International Conference on Online Communities and Social Computing.

Jeppesen, L. B., \& Molin, M. J. (2003). Consumers as co-developers: Learning and innovation outside the firm. Technology Analysis \& Strategic Management, 15(3), 363-383.

Kim, J. B. (2012). An empirical study on consumer first purchase intention in online shopping: integrating initial trust and TAM. Electronic Commerce Research, 12(2), 125-150.

Kim, S.-B., Sun, K.-A., \& Kim, D.-Y. (2013). The influence of consumer value-based factors on attitude-behavioral intention in social commerce: The differences between high-and low-technology experience groups. Journal of Travel \& Tourism Marketing, 30(1-2), 108-125.

Kim, S., \& Park, H. (2013). Effects of various characteristics of social commerce (s-commerce) on consumers' trust and trust performance. International Journal of Information Management, 33(2), 318-332.

LaCoursiere, S. P. (2001). A theory of online social support. Advances in Nursing Science, 24(1), 60-77.

Liang, T.-P., \& Turban, E. (2011). Introduction to the special issue social commerce: a research framework for 
social commerce. International Journal of electronic commerce, 16(2), 5-14.

Linda, S.-1. L. (2010). Social Commerce---E-Commerce in Social Media Context. World Academy of Science Engineering and Technology, 72, 39-44.

Liu, L., Cheung, C. M., \& Lee, M. K. (2016). An empirical investigation of information sharing behavior on social commerce sites. International Journal of Information Management, 36(5), 686-699.

Lu, Y., Zhao, L., \& Wang, B. (2010). From virtual community members to C2C e-commerce buyers: Trust in virtual communities and its effect on consumers' purchase intention. Electronic Commerce Research and Applications, 9(4), 346-360.

Madjar, N. (2008). Emotional and informational support from different sources and employee creativity. Journal of Occupational and Organizational Psychology, 81(1), 83-100.

Mutz, D. C. (2005). Social trust and e-commerce experimental evidence for the effects of social trust on individuals' economic behavior. Public Opinion Quarterly, 69(3), 393-416.

Nunnally, J. C., \& Bernstein, I. (1994). The assessment of reliability. Psychometric theory, 3(1), 248-292.

Obst, P., \& Stafurik, J. (2010). Online we are all able bodied: online psychological sense of community and social support found through membership of disability-specific websites promotes well-being for people living with a physical disability. Journal of Community \& Applied Social Psychology, 20(6), 525-531.

Pavlou, P. A. (2003). Consumer acceptance of electronic commerce: Integrating trust and risk with the technology acceptance model. International Journal of electronic commerce, 7(3), 101-134.

Preacher, K. J., \& Hayes, A. F. (2008). Asymptotic and resampling strategies for assessing and comparing indirect effects in multiple mediator models. Behavior research methods, 40(3), 879-891.

Reychav, I., \& Weisberg, J. (2010). Bridging intention and behavior of knowledge sharing. Journal of knowledge management, 14(2), 285-300.

Ridings, C. M., \& Gefen, D. (2004). Virtual community attraction: Why people hang out online. Journal of Computer-Mediated Communication, 10(1), 00-00.

Ringle, C. M., Wende, S., \& Will, S. (2005). SmartPLS 2.0 (M3) Beta, Hamburg 2005.

Saundage, D., \& Lee, C. Y. (2011). Social commerce activities-a taxonomy. Paper presented at the ACIS 2011: Identifying the information systems discipline: Proceedings of the 22nd Australasian Conference on Information Systems.

Saunders, M. N. (2011). Research methods for business students, 5/e: Pearson Education India.

Senecal, S., \& Nantel, J. (2004). The influence of online product recommendations on consumers' online choices. Journal of retailing, 80(2), 159-169.

Shanmugam, M., Sun, S., Amidi, A., Khani, F., \& Khani, F. (2016). The applications of social commerce constructs. International Journal of Information Management, 36(3), 425-432.

Shi, S., \& Chow, W. S. (2015). Trust development and transfer in social commerce: prior experience as moderator. Industrial Management \& Data Systems, 115(7), 1182-1203.

Shin, D.-H. (2010). The effects of trust, security and privacy in social networking: A security-based approach to understand the pattern of adoption. Interacting with computers, 22(5), 428-438.

Shin, D.-H. (2013). User experience in social commerce: in friends we trust. Behaviour \& information technology, 32(1), 52-67.

Stone, M. (1974). Cross-validatory choice and assessment of statistical predictions. Journal of the royal statistical society. Series B (Methodological), 111-147.

Swamynathan, G., Wilson, C., Boe, B., Almeroth, K., \& Zhao, B. Y. (2008). Do social networks improve ecommerce?: a study on social marketplaces. Paper presented at the Proceedings of the first workshop on Online social networks.

Tabachnick, B. G., Fidell, L. S., \& Osterlind, S. J. (2001). Using multivariate statistics.

Tenenhaus, M., Vinzi, V. E., Chatelin, Y.-M., \& Lauro, C. (2005). PLS path modeling. Computational statistics \& data analysis, 48(1), 159-205.

Vatanasombut, B., Igbaria, M., Stylianou, A. C., \& Rodgers, W. (2008). Information systems continuance intention of web-based applications customers: The case of online banking. Information \& management, 45(7), 419428.

Wang, C., \& Zhang, P. (2012). The evolution of social commerce: The people, management, technology, and information dimensions. Communications of the association for information systems, 31(5), 1-23.

Wang, J.-C., \& Chang, C.-H. (2013). How online social ties and product-related risks influence purchase intentions: A Facebook experiment. Electronic Commerce Research and Applications, 12(5), 337-346.

Weber, K., Johnson, A., \& Corrigan, M. (2004). Communcating emotional support and its relationship to feelings of being understood, trust, and self-disclosure. Communication research reports, 21(3), 316-323. 
Weisberg, J., Te'eni, D., \& Arman, L. (2011). Past purchase and intention to purchase in e-commerce: The mediation of social presence and trust. Internet research, 21(1), 82-96.

Werts, C. E., Linn, R. L., \& Jöreskog, K. G. (1974). Intraclass reliability estimates: Testing structural assumptions. Educational and psychological measurement, 34(1), 25-33.

Wigand, R. T., Benjamin, R. I., \& Birkland, J. L. (2008). Web 2.0 and beyond: implications for electronic commerce. Paper presented at the Proceedings of the 10th international conference on Electronic commerce.

Yang, M.-H., Lin, B., Chandlrees, N., \& Chao, H.-Y. (2009). The effect of perceived ethical performance of shopping websites on consumer trust. Journal of computer information systems, 50(1), 15-24.

Yaseen, A. (2015). Collaborative innovation in the Pakistan's dairy industry: effectiveness of managerial leadership and organizational readiness.

Zeng, F., Huang, L., \& Dou, W. (2009). Social factors in user perceptions and responses to advertising in online social networking communities. Journal of interactive advertising, 10(1), 1-13. 